\section{PP-493 IVRを行った泌尿器科的疾患12例の検討} 中央病院放射線科2)

山形県立中央病院泌尿器科1，山形県立

尾形 幸彦 ${ }^{1)}$ ，津久井 秀則 ${ }^{11}$ ，山室 拓 ${ }^{1)}$, 沼烟 健司 ${ }^{1)}$, 菅野 理 ${ }^{1)}$, 星 宣次 ${ }^{1,2)}$, 斉藤 聖宏 ${ }^{2)}$

IVR（interventional radiology）は腎血管性病変に対し、 腎機能温存の点からも優れた治療法である。今回、我々は IVR で治療を行なった泌尿器科的疾患 12 例について検討 したので、若干の考察を加えて報告する。【対象】2004 年 01 月〜 2009 年 12 月までの 6 年間に当科を受診し、当院 放射線科に依頼して、DSA 及び塞栓術を行なった 12 症例。 【症例】男性 6 例、女性 6 例。年齢 $36 \sim 77$ 歳、中央值 47 歳。症例の内訳は、腎外傷 2 例、腎血管筋脂肪腫 (AML) 破裂 5 例、腎動静脈瘦 2 例、腎動脈瘤破裂 2 例、その他 1 例。 全例 DSA を行い、術前に診断がつかなかったり、診断が 異なっていたものは可及的に診断を確定させた上で、同時 に治療も行なった。 \section{PP-495 大量の腹水流出で発見された膀胱破裂の
1 例}

大阪暁明館病院泌尿器科 ${ }^{1)}$ ，大阪暁明館病院内科 ${ }^{2)}$

川上 隆 ${ }^{1}$, 坂 宗久 ${ }^{1)}$, 近藤 秀明 ${ }^{12}$, 片岡 康雄 ${ }^{2}$, 牧野 晋也 ${ }^{2)}$

【症例】 53 歳、女性。【主訴】歩行困難、食意不振【既往 歴】10 年前まで $\mathrm{B}$ 型肝炎にて加療もその後放置。【現病歴】 1 ケ月前から徐々に腹部緊満になり歩行困難となったため 平成 21 年 4 月上旬当院に救急搬送、肝硬変による多量の 腹水を認められ、同日入院となる。【人院時所見】意識鮮 明、腹部緊満にて腹部 US 検査で腹水多量に求められた。 Plt $6.9 \times 104$ T-Bil 9.6mg/dl AST 132IU/1 ALT 45IU/1 と 異常值を認めた。【入院後経過】入院時より点滴・腹水穿 刺施行も、再度腹水貯留後、尿道カテーテルより廃液が多 量排出、腹部緊満も消失したため膀胱破裂の疑いで当科紹 介。同日膀胱造影にて膀胱外造影剂漏出を認められ、両側 尿管にS-Jカテーテルを留置、25 日後膀胱鏡にて膀胱破裂 部位の修復確認できたが肝硬変の增覀にて死亡。【考察】 膀胱破裂は外傷性と自然に、自然破裂は症候性と続発性に 分類され、放射線照射後や病的膀胱、飲酒後が多い。破裂 部位の遊離腹腔内への交通、腹腔内への尿漏出の有無から 後腹膜破裂と腹腔内破裂に分類され、腹腔内破裂では腎不 全と同一の病態を呈することや沉発性腹膜炎と診断される ことも知られているが、本症例では尿道カテーテルから大 量の腹水が流出したことと即座に両側尿管にS-J カテーテ ルを留置したためその症状を呈さなかった。

\section{PP-496＼cjkstart骨盤内放射線療法に伴う尿路障害に対す る外科的治療の経験}

\section{東京女子医科大学泌尿器科}

鈴木 裕子, 小内 友紀子, 田邊一成

【はじめに】尿管ステント留置による尿路症状、疼痛など は患者の QOL を低下させる。今回、尿管ステントを 2 種 類使用し、ステントが患者に与える影響について前向き比 較試験を行ったので報告する。【対象と方法】対象は 2009 年 6 月から 8 月の間に尿管ステントを留置した 15 症例。 平均年齢 55.3 歳、男女比は 8; 、尿管ステントはバードイ ンレイステント (A 群) が8例、ボストンパーキュフレッ クスステント (B 群) 7 例 (A 群と B 群は無作為に振り分 けた)、初回留置症例が 4 例、交換症例が11 例であった。 評価は IPSS と OAB - SS、VAS、持続する肉眼的血尿の 有無で評洒した。それぞれステント挿入前、挿入後 1 週間 目、4 週間目で評価した。【結果】留置後 1 週間目の点数 は、A 群で IPSS 9、QOL 2.71、OAB-SS 3.57、VAS 1.14、 B 群で IPSS 6.86、QOL 2.71、OAB-SS 2.86、VAS 2.28 で あり、すべての評価で A 群と B 群に有意差が認められな かった。 1 週間目と 4 週間目でも有意差は認められなかっ た。ステント留置後 1 週間目と 4 週間目で、持続する血尿 を認めた症例は A 群 B 群ともなかった。留置から血尿が 無くなるまでの日数は、A 群で 0.6 日、B 群で 1.6 日で、 こちらも有意差はなかった。【まぬ】ステントの種類に より明らかな尿路症状、血尿、痛みに有意差はなかったが、 今後、症例数を増やし、さらに評価を行っていく必要があ ると思われた。

\section{北海道大学医学部泌尿器科学 ${ }^{1)}$, 旭川厚生病院泌尿器科 ${ }^{2)}$, 留萌市立病院 ${ }^{3)}$}

村橋 範浩 ${ }^{12}$, 田中 博 ${ }^{1)}$, 大澤 崇宏 ${ }^{11}$, 菊地 央 ${ }^{1)}$, 鴨田 慎二 ${ }^{22}$, 千葉 博基 ${ }^{3)}$, 三井 貴彦 ${ }^{1)}$, 篠原 信雄 ${ }^{1}$, 野々村 克也 ${ }^{1)}$

[目的］骨盤内放射線療法に伴う尿路障害は膀胱炎症状以 外に瘻孔や消化管病変の合併など多彩な病態をとる。今 回、骨盤内放射線療法後に異なる病態を示した 3 例に対す る外科的治療を経験したので報告する。[対象と方法］刘 象は骨盤内放射療法に伴う尿路障害に対し、外科的な治療 を行った 3 例であり、それぞれの症例の病態と外科的治療 方法に関して検討した。[結果］症例 1 は34歳女性。小見 期に左卵巣癌にて手術、化学療法、さらに骨盤内放射線療 法を施行され、難治性の頻尿と血尿あり受診。膀胱の広範 な病変と萎縮を認めた。外科的治療として膀胱摘出術、回 盲部から横行結腸を用いた禁制型代用膀胱を形成した。症 例 2 は 32 歳女性。子宮頸癌にて子宮全摘と放射線照射後 に膀胱腔瘦を発症した。膀胱出血はないものの、大きな膀 胱膣瘦を認めた。瘦孔の大きさから感染の危険性は低いと 判断し、膀胱は空置したまま結腸と胃による禁制型代用膀 胱を作成した。症例 3 は 50 歳女性。子宮癌にて子宮全摘 と放射線照射を受け、膀胱タンポナーデと膀胱破裂、S 状 結腸に放射線による高度狭窄を認め入院。膀胱と S 状結 腸の摘出、結腸末端部による結腸導管と、人工肛門を造設 した。[結論］骨盤内放射線膀療法後の尿路障害に対する 外科的治療は、患者個々の病態を十分に考慮し適切な術式 を選択する必要がある。 